\title{
RECEPTIVE CULTURAL FACTORS OF SARAJEVO TOURISM DESTINATION
}

\author{
Lejla Žunić
}

\begin{abstract}
Sarajevo tourist destination has a favorable tourist-geographical position because it is located on an important European tourist corridor used by Central European tourist clientele to circulate towards the Adriatic Sea. At the same time, Sarajevo is the capital city of Bosnia and Herzegovina and therefore is the most important geographic, geotraffical, political, cultural and tourist center (1/3 of total tourism in Bosnia \&Herzegovina). The destination of Sarajevo has an extremely valuable tourism potential (natural and anthropogenic) but according to statistical indicators in the last decade it has had a positive trend of tourism development (moderate to high rates of increase in the number of tourists and overnight stays, accommodation, etc.). It is therefore very important to analyze the receptive cultural factors of tourism: serviceability and content of the tourist stay. These factors largely affect the attractiveness of a destination and its sustainable tourism development. The problem of the paper is identification and valorisation/ evaluation (assessment) of receptive cultural factors and relevant parameters. The aim of the paper is to identify cultural factors of tourism and thier value important for tourism destination development. Research methods are: analysis, identification, classification, field work, surveys, evaluation, Likert method, synthesis. Field work includes: observations, surveys, interviews and other methods of data collection (from relevant institutions). The survey included more than 200 subjects (tourism employers and employees, tourists, tourist carriers) and it allowed to come to important insights regarding the evaluation of receptive cultural factors of Sarajevo tourism. These factors have a favorable tourist value and represent an important predisposition for planning and development of tourism in the destination of Sarajevo.
\end{abstract}

Key words:tourism destination, receptive cultural factors, identification, evaluation, tourism development.

\section{INTRODUCTION}

Receptive cultural factors have been identified as important factors of tourism (Lohman, 2004, Robinson, 2014, SETE, 2011), they are the factors of offer (Dobre, 2005), factors of tourist receptive (Jovičić, 1986), and complete services in the destination (Blažević and Pepeonik, 1993). According to Jovičić, receptive cultural factors are: hospitality/ serviceability and content of tourist stay. Reference parameters of hospitality are: professional qualifications of tourism staff, other qualifications, language skills, and kindness to the tourist clientele. Indicators of tourist stay are: accommodation, food, motives, services, program of stay.

\section{METHODOLOGY}

The problem and subject of the research is the identification and tourist evaluation of

${ }^{1}$ Doctor of Geographical Sciences, Department of Geography, Faculty of Science, University of Sarajevo, Zmaja od Bosne 33 - 35, 71000 Sarajevo; pmflejlazunic@yahoo.com. 
receptive cultural factors. The aim of the paper is to carry out identification and evaluation of receptive cultural factors and reference parameters, and based on the determined value (ranking) to determine their tourism quality. There were used general scientific and geographic methods: analysis, synthesis, classification, evaluation, identification, ranking, surveying, cartographic method, field work. Tourist geographical valorisation of the factors and parameters relies on classic WTO valorisation model (evaluation method), as well as measuring on the Likert scale. WTO(World Tourism Organisation) model is based on the standard formulars that can be used for identification as well as for the assessment of value and ranking parameters. (Stanković, 2000) The identification method has enabled identification of cultural factors of tourist receptive. Surveying allowed to come to important insights, it took two years (2013-2014), was conducted in the Sarajevo tourist destination in the most important tourist sites and included nearly 200 participants (travel managers and workers, tourists-visitors). Interviewing travel managers (20) and workers (59) was carried out in several hotels (the Bristol $4 *$, the Europe $5 *$, the Art $3 *$, the Terme $4 *$, the Hercegovina $4 *$, the Crystal $4 *$, the Hollywood $4 *$, the Dardania $3 *$, the Holiday $4 *$ ) and travel agencies (Relax Tours, Gaudi Lufthansa, Avio Express, Kompass, Sol Azur, Bosnia Travel, Reyyan, Akdeniz, Euroservices, ZOI'84). The surveys of tourists (107) were conducted on: a) tourist sites in the old city (garden of the Morić Han, harem of the Bey's Mosque), b) tourist accommodation units: hotels (the Europe, Radon Plaza, Bristol, Hollywood, Terme, Dardania, Imzit, Astra Garni, Michele, Old Town, ETN, Mostardayiz, City Boutique, Emona, Lula), hostels (the Vagabond, Franz Ferdinand, Kovači, Max, Guest House, For Me, Doctor's House), private accommodation, and Sarajevo apartments. The structure of respondents is of different ages, about $40 \%$ are the tourists of Arab origin, and then other foreign tourists (Turkey, the United States, Canada, Malaysia, Japan, etc.) and domestic tourists (from Bosnia and Herzegovina).

\section{RESULTS AND DİSCUSSION}

Hospitality means "taking care of customers" (Tomašević, 2009) and "serving with the aim to make customers feel at home" (Brotherton, 1999). The research on the rising number of employees in catering industry and tourism of Sarajevo aaccording to professional qualifications showed a positive growth of secondary school, college and university degrees, although the largest share has secondary school degree with $41 \%$ (Federal Office for Statistics of Bosnia \& Herzegovina, 2011). 


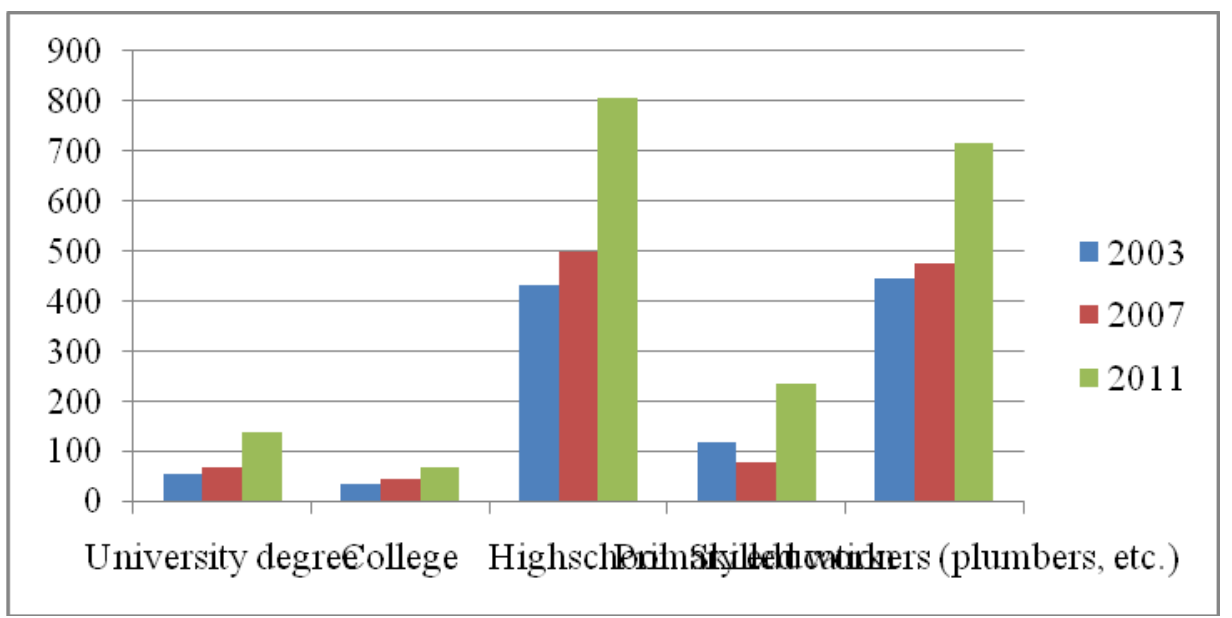

Fig. 1. Growth in number of employees at hospitality and tourism of Sarajevo according to their qualifications (title) in the period of 2003-2011

(The Archive of Federal Office of Statistics, Federation of Bosnia and Herzegovina, Sarajevo)

The structure of titles is adequate (the largest share is of hotel and tourism technicians) but it is evident that there are inadequate profiles engaged to perform tourist activities (eg, a dental technician, a theologian, a textile technician). The reason is nepotism which is largely present in the tourism industry (around half the workers, many of them got the job on the basis of personal recommendations without the need of proving the qualifications).
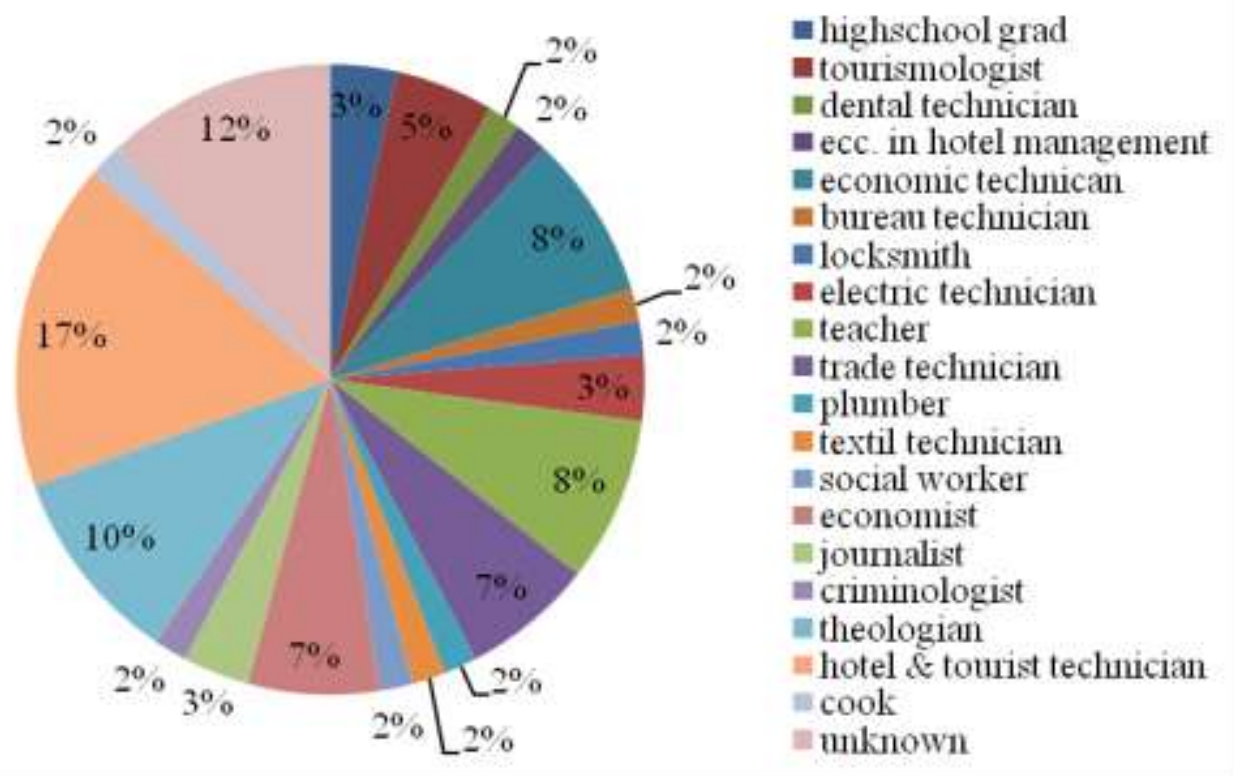

Fig. 2.Professional degree in tourism workers (employees) in Sarajevo

(Survey for employees in tourism, Sarajevo, 2013) 
The occupational structure is relatively heterogeneous (one-third is of the reception) but as "tourism industry provides more than 400 different professions" (Canadian Tourism HR Council, 2013), it is possible and necessary to develop a range of occupations in the tourism of Sarajevo.

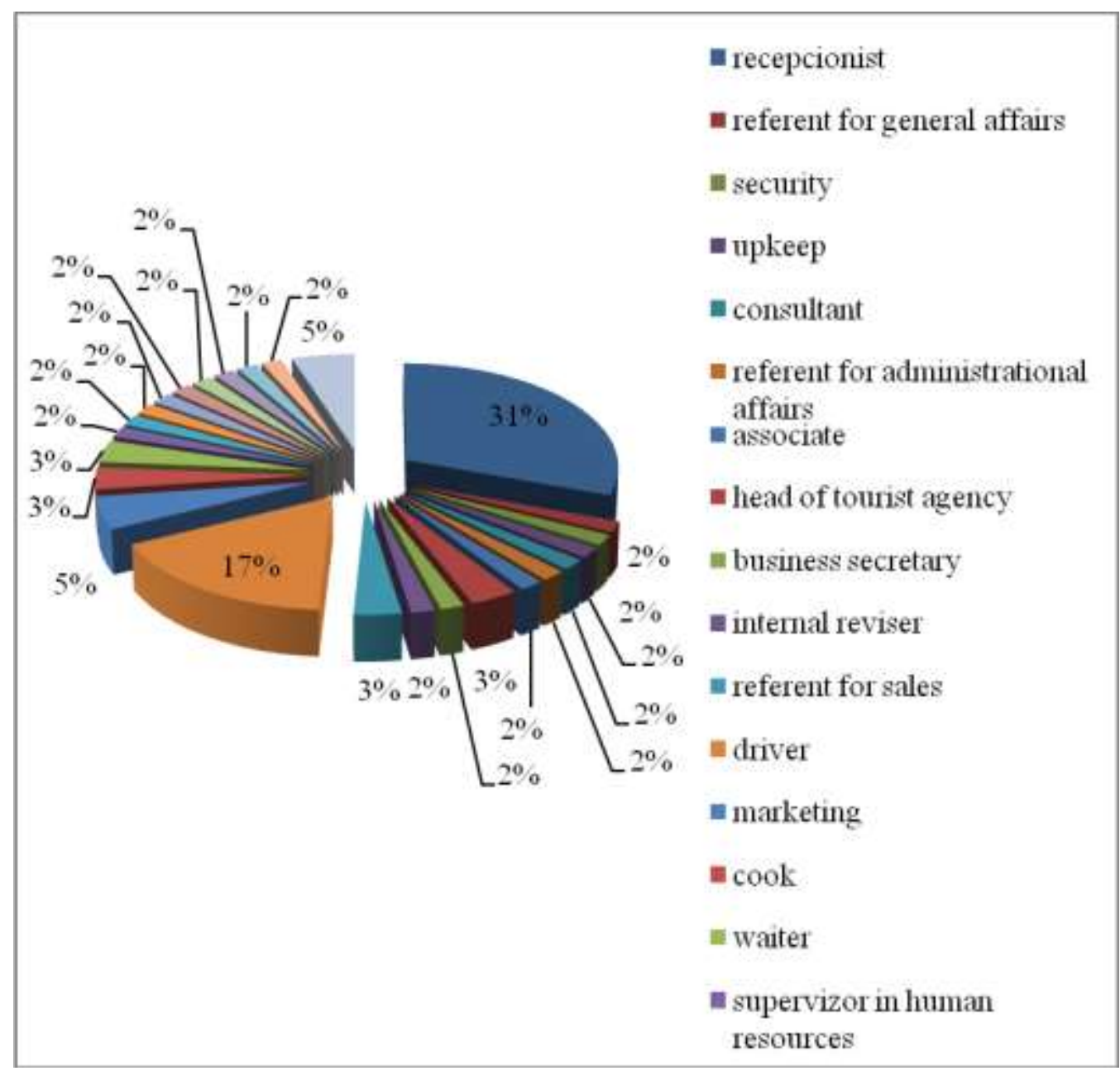

Fig. 3.Job profile and position in tourism workers in Sarajevo

(Survey for employees in tourism, Sarajevo, 2013)

91.5\% of tourism workers speak and use English very well to excellent, and in addition to English there is a need for knowledge of Arabic and Turkish, as imposed by the structure of visitors. "In the structure of foreign arrivals the largest share take tourists from Turkey (17.3\%), Croatian (16.7\%), Slovenia (7.0\%), Serbia (4.9\%) and Germany (3.7\%). In the structure of foreign overnight stays in 2013, the largest share take again tourists from Turkey (16.8\%), Croatian (14.8\%), Kuwait (5.8\%), Slovenia (5.7\%) and Serbia (4, 6\%). (Tourism Association of Sarajevo Canton, 2013) 


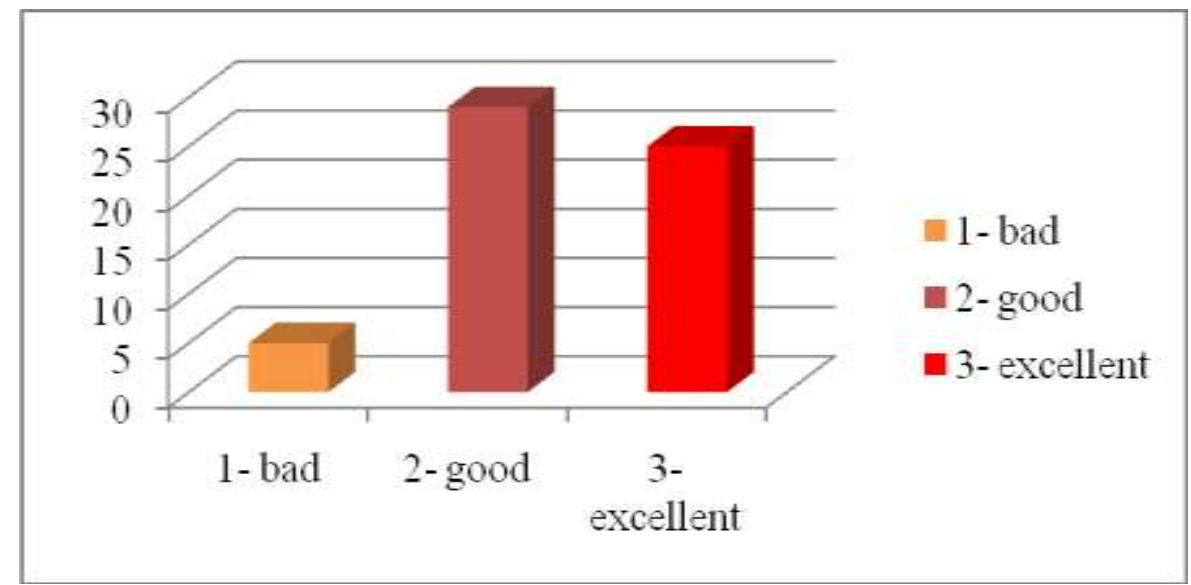

Fig. 4.English language skills in tourism workers

(Survey for employees in tourism, Sarajevo, 2013)

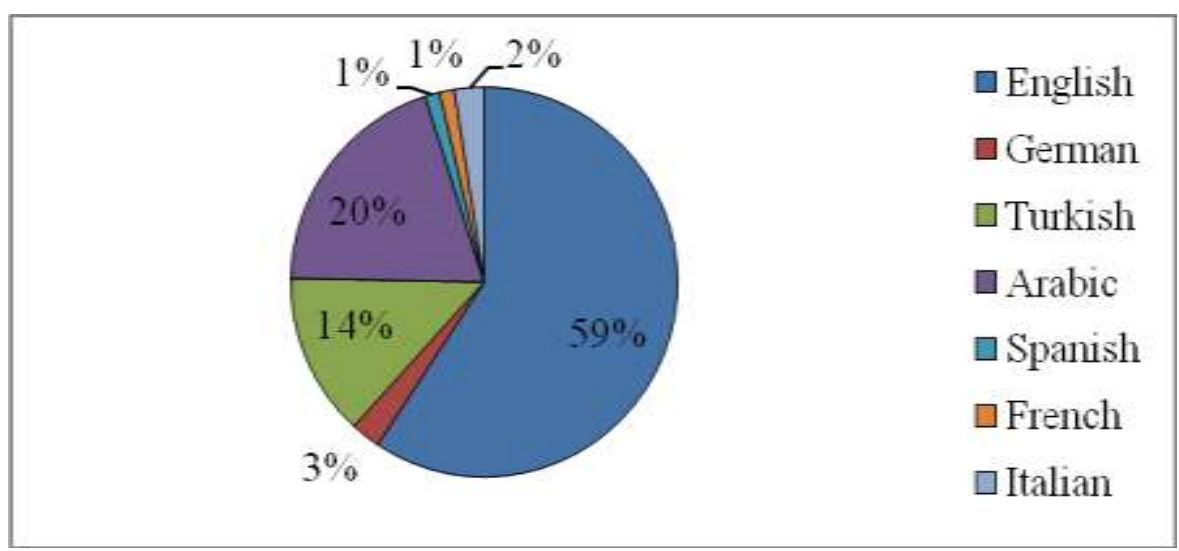

Fig. 5.Required languages for tourism purposes

(Survey for employees in tourism, Sarajevo, 2013)

Culture of tourism is "cultural practice and benefits of tourism" (Tittonghkam and Walsh, 2010) while the hospitality of tourism workers in the destination is good (65$66 \%)$ and the local population is approachable - affable (88-90\%). 


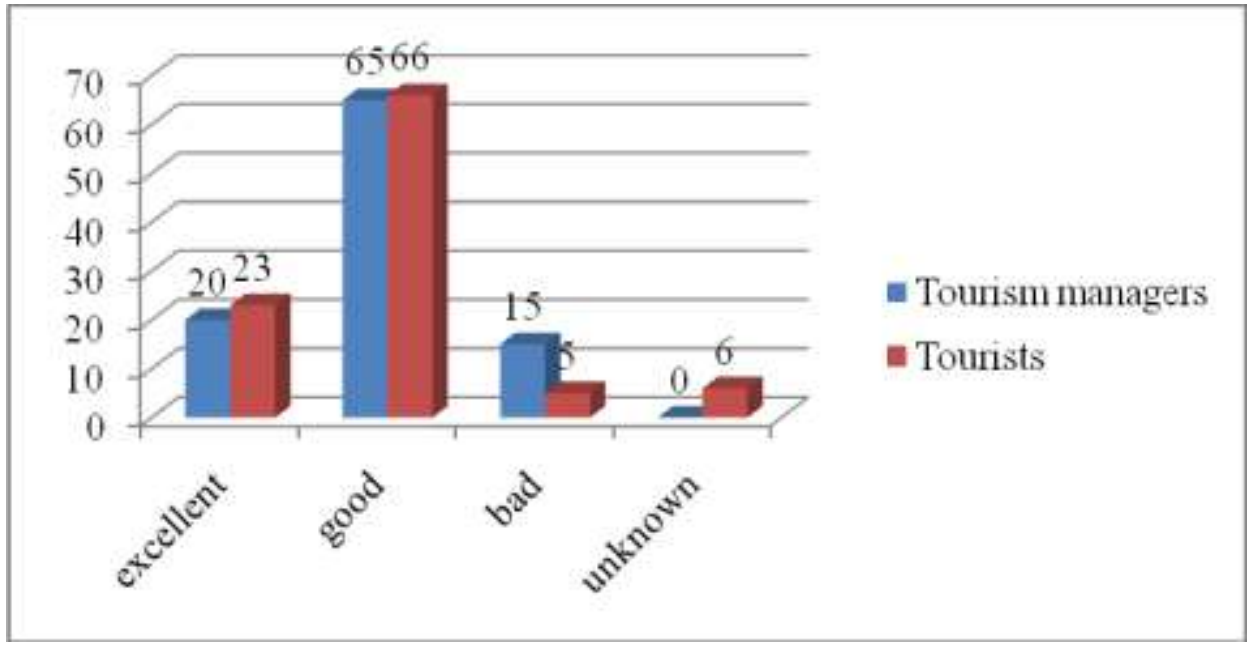

Fig. 6.Affability in tourism workers in Sarajevo (in percentage)

(Survey for employers in tourism, Sarajevo, 2013; Survey for tourists, Sarajevo, 20132014)

The content of tourist stay is manifested through variables of the destination: accommodation, motives, services, and so on. The total average rate of increase of accommodation in Sarajevo tourist destination is favorable and amounts to 9.8\% (19992009 ) with the largest concentration of buildings in the old town.

Table 1. Growth rates in the accommodation capacities in period 1999-2009

\begin{tabular}{|l|r|r|r|c|}
\hline & 1999 & 2004 & 2009 & Growth rate (\%) \\
\hline Accomodation & 22 & 34 & 55 & 9,8 \\
\hline Rooms & 882 & 1762 & 2753 & 16 \\
\hline Beds & 1604 & 3546 & 5488 & 17 \\
\hline
\end{tabular}

(Đuzo, 2010. Author)

Accommodation services are good to excellent (over $80 \%$ ).

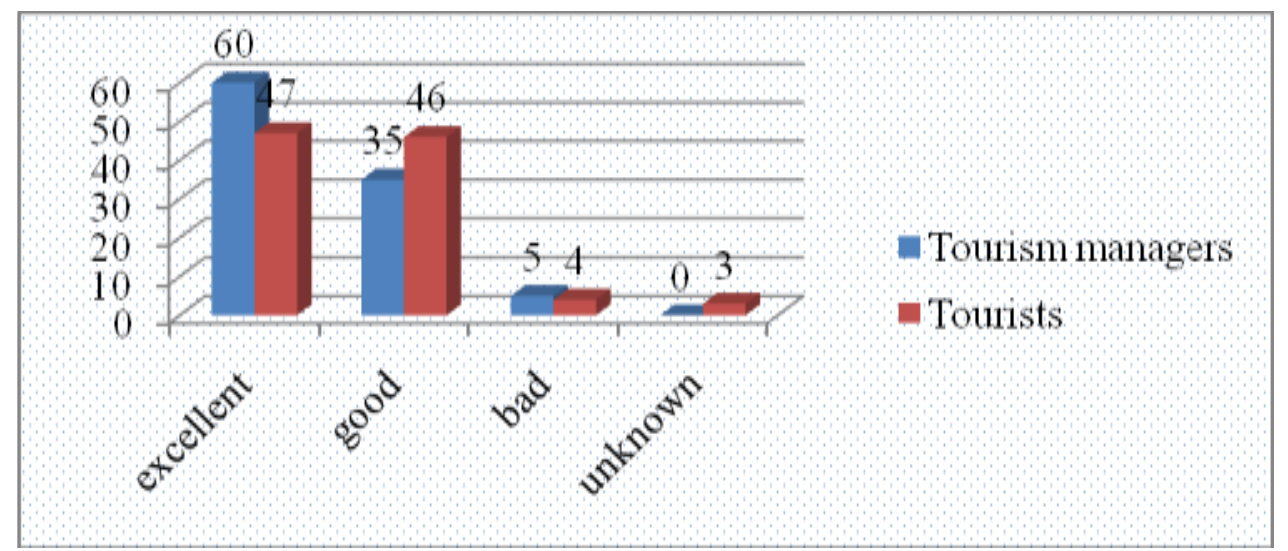

Fig. 7.Accommodation services inSarajevo (in percentage)

(Survey for tourists, Sarajevo, 2013-2014) 
The gastronomic offer is very important segment of the tourist offer (Kovačević, 2003), it has initiated the development of gastronomy (culinary) tourism (International Culinary Tourism Association, USA) and in Sarajevo it has been assessed as very favorable, food and drink offer has an excellent tourist quality, while traditional Bosnian dishes (eg. ćevapi - a dish of obelisk-shaped minced meat ) were identified at the World list of ideal foods (Oliver, 2014).

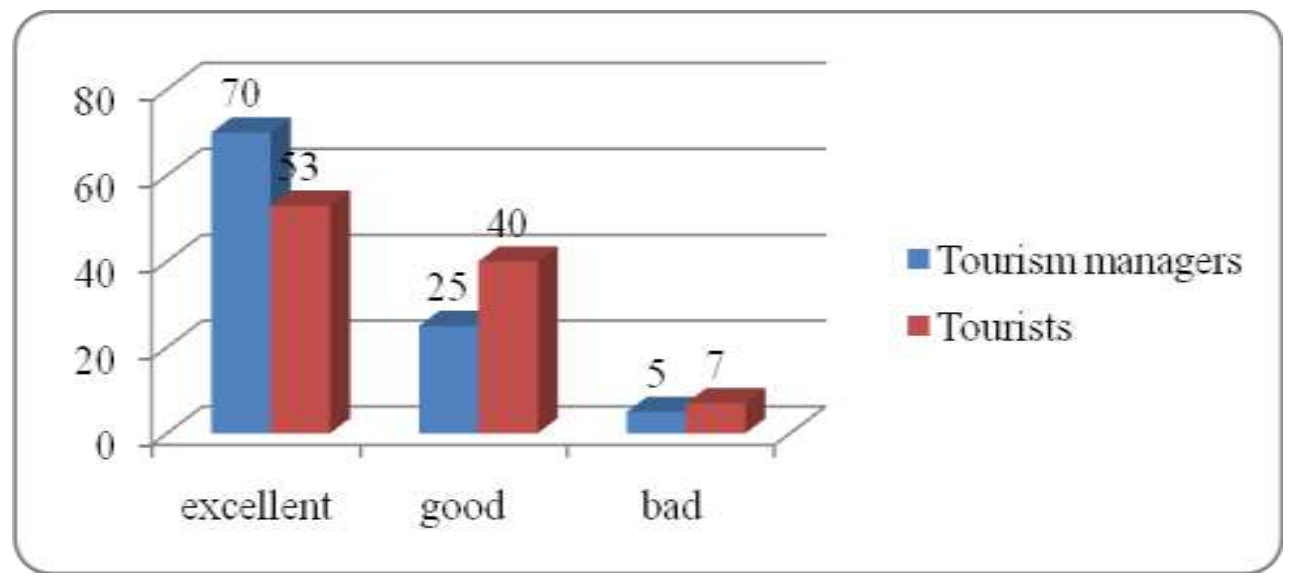

Fig. 8. Gastronomic offerin Sarajevo (in percentage)

(Survey for employers in tourism, Sarajevo, 2013; Survey for tourists, Sarajevo, 20132014)

The motives of Sarajevo are numerous (natural and anthropogenic) because it is the capital city of Bosnia and Herzegovina with a rich cultural and historical heritage; the greatest value has the one from the Ottoman and Austro-Hungarian period, Sarajevo is a "unique symbol of universal multiculture" (Commission to Preserve National Monuments, Bosnia and Herzegovina, 2005, UNESCO, 2015). Potential forms of tourism are: culture, event, gastronomy, mountain and recreational excursion, caving, eco-tourism, congress, urban. 
Table 2.Top tourist attractions in Sarajevo

\begin{tabular}{|l|c|c|}
\hline & Significance & Rank \\
\hline NATURAL ATTRACTIONS & & 1 \\
\hline Mountains (Bjelašnica, Igman) & International & National \\
\hline Waters (Springs of Bosnia, thermal water- bath Ilidža) & & \\
\hline ANTROPOGENIC ATTRACTIONS & International & 1 \\
\hline Environment (Baščaršija, Downtown) & National & 2,1 \\
\hline Bridges (Kozja ćuprija, The Latin Bridge) & National & 1 \\
\hline Realigious (Kuršumli medresa, Sebilj česma) & National & 2 \\
\hline Cultural(City Hall, National Theatre, Bosnian Presidency) & International & 1 \\
\hline Mosques (Gazi Husrev Bey's, Emperor's) & National & 2 \\
\hline Churches (Congregational Church, Cathedral) & National & 2 \\
\hline Synagogeus (Ashkenazi, The Old Temple) & International & 1 \\
\hline Cemeteries (Alifakovac, Bey's turbeh) & National & 2 \\
\hline Memorials (Eternal flame, Vrace, Markale) & National & 2 \\
\hline Museums (The National; Alija; Bezistan, Svrzo, Despić) & National & 2 \\
\hline Buildings (Artisticum BiH, Bosniak Institute) & International & 1 \\
\hline Collections (Sarajevska hagada, the Museum's) & International & 1 \\
\hline Libraries (Gazi Husrev Bay) & Regional & 3 \\
\hline Fun \& recreational parks (Peeonir's Valley) & & \\
\hline
\end{tabular}

$$
\text { (Žunić, 2016) }
$$

Services in the destination generally have a good travel quality: banks, market/ shopping, while tourist information is slightly lower rated. The reason is lake of tourist informators and navigation and thematic maps, as well as insufficient promotion of the Sarajevo destination.

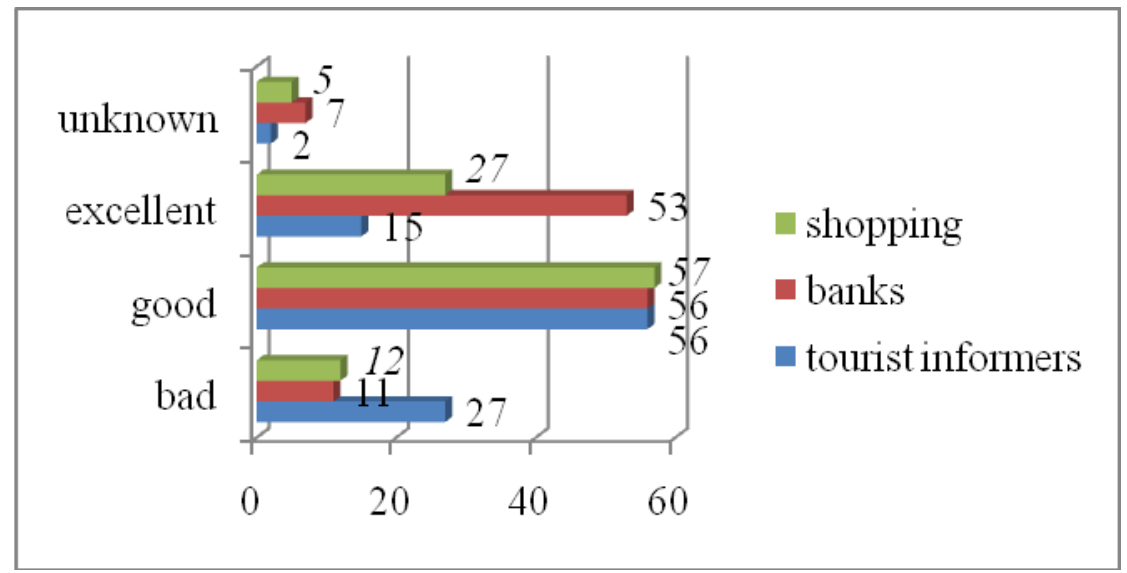

Fig. 9. Complementaryservices: tourist informers, banks, shopping (\%) (Survey for employers in tourism, Sarajevo, 2013; Survey for tourists, Sarajevo, 20132014) 
The stay program offers a product that promotes basic tourist activities: $50 \%$ promotion of heritage, $15 \%$ shopping and 35\% entertainment, it is considered to be optimal for stays of 3 days (Mehičić, 2007). Events are developing, they are important because they "make 20\% of the total tourist income in European capitals" (Marjanović, 2012). The topics of the Sarajevo events are different but the most important are cultural, for example Sarajevo Film Festival which takes on an international importance because it has a positive growth of visits of foreign tourists and recognizable image (visits by the big Hollywood stars Brad Pitt and Angelina Joly). The total average rating of the receptive cultural factors of Sarajevo tourist destination has moderate to elevated value (2.4), and has a very good tourist quality (I-II quality range, excellent to good quality). The content of tourist stay (I) has a better assessment than serviceability (II), and is a particularly important factor in the destination tourism development. Especially valuable are: cuisine, motives, accommodation. (Žunić, 2016)

Table 3. Evaluation of receptive cultural factorsin Sarajevo tourism

\begin{tabular}{|l|c|c|}
\hline Factors and parameters of evaluation: & Average mark & Scale \\
\hline F1: Hospitality & & \\
\hline F1-I: Professional degree in tourism workers & 2,8 & $0-4$ \\
\hline F1-II1: Affability of tourism workers & 2,2 & $1-3$ \\
\hline F1-II2: Affability of inhabitants & 0,9 & $0-1$ \\
\hline F2: The content of tourist stay & & \\
\hline F2-I: Accommodation & 2,4 & $1-3$ \\
\hline F2-II: Food \& drink & 2,6 & $1-3$ \\
\hline F2-III1: Attractions & 4,4 & $3-5$ \\
\hline F2-III2: Access attractions & 1,6 & $1-3$ \\
\hline F2-IV1, 2, 3: Services (together) & 2,1 & $1-3$ \\
\hline F2-IV1: Tourist informers & 1,9 & $1-3$ \\
\hline F2-IV2: Banks & 2,3 & $1-3$ \\
\hline F2-IV3: Shopping & 2,2 & $1-3$ \\
\hline F2-V: The stay program & 2 & $1-3$ \\
\hline F2-VI: Manifestation & 3,6 & $1-3$ \\
\hline Overall average: & 2,4 & $1-3$ \\
\hline
\end{tabular}

(Žunić, 2016)

\section{CONCLUSION}

Receptive cultural factors have a very good quality of tourism and will have a significant impact on the design of tourism offer, promotion of the destination and ways to use them for tourism purposes. As "the tourist receptive is the basis of each destination as well as the outcome and condition for creating optimal tourism product" (Crnogorac, Babić, 2003), so receptive cultural factors represent the leading attribute factor in further development of tourism in Sarajevo. Particularly important are: 
gastronomy, motives, events, accommodation, affability of people and professional qualifications of tourism workers.

Problems are associated with a lower value of some basic services, eg. tourist information, which need to be improved in the way to bring a larger number of tourist information spots, to mark tourist trails and signs better, to make tourist brochures and maps available at various locations, even in public transport, then to highlight and protect the tourist-information boards, and to enable electronic info navigation for tourists. Besides, it is important to work on improvement of the marketing and promotion of the destination. On the ther hand, it's neccessary to develop tourism awareness and culture in people who work in the service sector (trade, catering, banks, etc.). There are also problems with the access to cultural property because there are large crowds at major tourist sites as well as in public transport, so that it requires more planning behind tourist visits and movement of tourists in the destination. Problems related to accommodation are related to lower utility infrastructure in the old town (possible reduction of water or a lack of hot water), then there are inferior interiors making it necessary to carry out monitoring, especially in better categorized units, because it is paradoxical that there are objections by the tourists there and it is also necessary to bring the accommodation decor to a higher level (better lighting, more vivid colors and the like). Moreover, it is necessary to introduce control and monitoring of the hospitality of tourism workers in order to raise the serviceability to the highest possible level. "It is necessary to develop and practice cultural intelligence (CQ) and tourist culture, because it is very important for the successful functioning in the relation to other people - guests, visitors, tourists, who have different cultural affiliation." (Yazici, 2016) Sarajevo has a lot to offer and the benefits of cultural receptive will significantly boost tourism trends and have an important share in the total tourist income of the destination.

\section{REFERENCES}

1. Blažević, I., Pepeonik, Z. (1993): "Tourism geography". School's book, Zagreb

2. Brotherton, B. (1999): "Towards a definite view of the nature of hospitality and hospitality management." International Journal of Contemporary Hospitality Management, vol. 11, no.4, p. 165-173

3. Crnogorac, Č., Babić, V. (2003): "Economical aspectsof tourism in themountain area ofbosnian municipaliy Teslić". Journal of Department for geography, tourismand hotel management, Tourism 7/2003, Faculty of Sciences University of Novi Sad, Novi Sad

4. Dobre, R. (2005): "Basics of tourism". Higher schoolfor tourism management, Šibenik

5. Jovičić, Ž. (1986): "Tourism geography". Scientific book, Beograd 
6. Commission to Preserve National Monuments of Bosnia and Herzegovina (2005).Resolution forthenational monuments declaration and tentative list of monuments, Bosniaand Herzegovina, 2005, Sarajevo

7. Kovačević, A. (2003): "The role and importance of gastronomy for hospitality and tourism development". «Tourism» no. 7, Faculty of Sciences University of Novi Sad, Novi Sad, pg 12

8. Lohman, M. (2004): "New Demand Factors in Tourism". Institut für Tourismusund Bäderforschung in Nordeuropa $\mathrm{GmbH}$, Kiel, Deutschland. Europian Tourism Forum, Budapest

9. Marjanović, J. (2012): "Opportunities and importance of the event tourism in the case of Zlatibor." Master rad. University of Singidunum, Belgrad, 2012

10. Mehičić, I. (2007): "Touristproduct of Canton Sarajevo- Sarajevoquality- basic elements". Chamber of Economy of Sarajevo Canton, Sarajevo

11. Nurković, S. (2006): "Regional aspect of tourism potentialsin Canton Sarajevoclassificationand evaluation."Proceedings Tourism as a factor of regional development,Faculty of Sciences of Universityof Tuzla, pg. 31-43

12. Oliver, J. (2014): "Jamie Oliver on Bosnian Cuisine". Sarajevo Times, 2014

13. Robinson, A. (2014). "Economic Factors in Tourism". eHow Contributor. Demand Media, Inc. Santa Monica, California, United States of America

14. Stanković, S. (2000): "Tourism Geography". University of Belgrad, Belgrad

15. The Archive of Federal Office of Statistics (2003-2011). Electronic data base. Federale Office of Statistics, Sarajevo, Federation of Bosnia and Herzegovina, Bosnia and Herzegovina

16. Thitthongkam, T., Walsh, J. (2010): "An Analysis of Factors Influencing the Competitiveness of the Thai Tourism Industry." Shinawarta International University, Bangkok, str. 138-141

17. Tomašević, A. (2009): "The Guest Care- in department for tourism \& hospitality". Agency for vocational education, British Council Montenegro, Regional project Skills\&Work

18. UNESCO »Culture», World Heritage Centre, »The List», Global Strategy, Tentative List, "Sarajevo - unique symbol of universal multiculture - continual open city", 1992-2015

19. The Survey Guide (2001): "Approaches to the Analysis of Survey Data". Statistical Services Centre, The University of Reading, United Kingdom

20. Yazici, S. (2016): "A New Challange of Tourism Employees: Cultural Intelligence". Presentation at 2. International Tourism and Hospitality Management Conference, October 12-16 2016, Sarajevo, Bosnia and Herzegovina

21. Zelenika, R. (2000): "Methodology and techniques of scientific and professional work". Faculty of Economics, University of Rijeka, Rijeka

22. Žunić, L. (2013): "Survey for employers in tourism". Sarajevo, 2013

23. Žunić, L. (2013): "Survey for workers (employees) in tourism". Sarajevo, 2013

24. Žunić, L. (2013-2014): "Survey for tourists- the visitors". Sarajevo, 2013-2014 
25. Žunić, L. (2016): "Tourism of Sarajevo- evaluationof receptive antropogenical factors and its importancefor planning the tourist offer". Doctoral dissertation. Mentor: PhD Kristina Košić. Faculty of Sciences of University of Sarajevo, Sarajevo

26. URL-1: http://fhtm.uitm.edu.my/v2/images/jthca/Vol4Issue2/chap-2.pdf

27. URL-2: http://traveltips.usatoday.com/culinary-tourism-1910.html

28. URL-3:

https://www.ic.gc.ca/eic/site/034.nsf/vwapj/Canadas_Federal Tourism_Strategyeng.pdf/\$file/Canadas_Federal_Tourism_Strategy-eng.pdf

29. URL-4:

http://kons.gov.ba/nacionalni_spomenici/privremena_lista/Default.aspx?id=7281\&1 angTag $=$ bs-BA

30. URL-5: http://kons.gov.ba 